\title{
妊娠中の呼吸・代謝機能の変化について \\ Respiratory and Metabolic Changes Corresponding to Gestational Stages
}

\author{
佐々木 敦 子 (Atsuko SASAKI)* 武 井とし子 (Toshiko TAKEI)* \\ 三 輪 百合子 (Yuriko MIWA)*
}

要約

妊婦体操や分婏時の呼吸法については，積極的な奖励により広く実施されている。

本研究は, 好娠の過程に伴う呼吸機能を測定し, 分婏時に用いられる呼吸法の指導に関する基礎的資 料を得ることを目的とした。

対象は正常経過の妊婦 8 人と非妊婦 25 人である。妊婦では, 妊娠初期, 中期, 後期の 3 回測定した。 内容は, (1)肺活量の測定, (2)呼気ガス分析 (呼吸法実施時, 運動負荷実施時), (3)心拍数 (運動負荷実施 時), (4)二酸化炭素分圧測定 (呼吸法実施時) である。呼吸法は腹式深呼吸, 胸式深呼吸, 短促呼吸およ び努責の代わりに息止めを行い，各呼吸法の間に安静 3 分間をとって実施した。運動負荷は安静 2 分間 を前後に 4 METS 設定で10分間実施した。結果より腹式深呼吸, 胸式深呼吸では呼吸効率は良いが, 短 促呼吸や息止めでは二酸化炭素の wash out 効率が悪いため, 十分な深呼吸が必要である。運動負荷によ る換気量や心拍数は, 妊娠の経過とともに増加した。

\section{Abstract}

Pregnancy and delivery bring complexed influences to the metabolism of the respiratory system.

The purpose of this investigation is to make accurate measurements of the respiratory function corresponding each gestational stage and to analyze the efficiency of gas exchange in the lung tissue.

The fundamental data during a certain breathing pattern, like that used for Lamaze's method, were also studied for the educational guidance of the pregnant women. Eight normal pregnant women were examined, and the results were as follows:

The vital capacity did not change through the pregnancy process. Energy consumption in the second and third trimesters of pregnancy increased significantly as compared with the first trimester of pregnancy.

In the second and third trimesters of pregnancy, the ventilatory volume and the heart rate during physical exercises have much more significantly increased than the first trimester of pregnancy.

Oxygen uptake and carbon dioxide $\left(\mathrm{CO}_{2}\right)$ exhaustion were gradedly increased with the additional

-信州大学医療技術短期大学部尃攻科助産学特別専攻 (Advanced Course in Midwifery, School of Allied Medical Sciences, Shinshu University) 
breathing exercises.

Decreasing ratio of the tissue partial pressure of carbon dioxide $\left(\mathrm{tcPCO}_{2}\right)$ showed 3 to $5 \%$ during abdominal and thoracic deep breathing patterns, while 2 to $3 \%$ during tachypneic breathing. There were significant differences between above two conditions.

These results revealed that the tachypneic breathing pattern was less effective for wash out function of $\mathrm{CO}_{2}$ from the tissue than the above mentioned deep breathing patterns.

In the breath holding operation, after more than one minute the $\mathrm{tcPCO}_{2}$ has been its maximum level. Therefore, it is indispensable to guide the deep breathing exercise just after bear down period.

\section{〈Key words〉}

gestational stage, vital capacity, energy consumption, Lamaze's method, breathing exercises

\section{I 緒 言}

奸娠，分婏による母体の生理的变化は，呼吸・ 代謝機能にも複雑な变化を招来する。

本研究においては, 妊娠の過程における呼吸機 能の測定と，運動負荷による呼吸循環系の機能測 定を実施し，妊娠の過程に伴う生理的変化を明ら かにし，その経時的変化から，エネルギー代謝状 況を検討した。

また，分婏時の呼吸法について，現在ラマーズ 法, リード法, 精神予防性無痛分婏法, ルーカス 法等さまさまな呼吸法が紹介され, 広く普及して きている。呼吸形式としては, 胸式呼吸を基本と したもの, 腹式呼吸を基本としたものがあり，呼 吸のリズムとしては分婏の進行に合わせ，ゆっく りとした深い呼吸から, 早めの浅い呼吸, あえぎ の呼吸等バリエーションもさまさまである。そこ で,これらの呼吸法による呼気ガス分析と組織内
二酸化炭素分圧の測定を実施し，呼吸効率の判定 を行い，分婏時のより良い呼吸指導を行うための 基礎的資料を得ることを目的とした。

\section{II 対 象}

対象は, 信州大学病院産婦人科外来受診中の正 常経過の妊婦で，昭和61年より昭和63年までの期 間に継続して測定しえた 8 人である。測定時期は 妊娠初期, 中期, 後期の 3 回について実施した。 また, 非妊婦25人を control として測定した。対象 の背景は，衰 1 に示すとおり，年㱓は20歳代であ り, 身長, 体重, 肥満度は呼吸機能について比較 検討できうる同程度の対象である。

\section{III 方 法}

\section{1. 内 容}

(1)肺機能測定 (立位安静時)

(2)呼気ガス分析 (運動負荷実施時, 呼吸法実施時)

表 1 対芜の背最

\begin{tabular}{|c|c|c|c|c|c|}
\hline 対象 & 非妊婦 & & 妊 & $=8)$ & \\
\hline 背景 & $(\mathrm{N}=25)$ & 非妊時 & 初 期 & 中 期 & 後 期 \\
\hline 年鮯(歳) & $\begin{array}{c}22.2 \\
(21 \sim 25)\end{array}$ & \multicolumn{4}{|c|}{$25.5(23 \sim 29)$} \\
\hline 身長 (cm) & $158.5 \pm 4.4$ & \multicolumn{4}{|c|}{$159.9 \pm 4.4$} \\
\hline 体重 (kg) & $51.2 \pm 5.3$ & $51.9 \pm 4.3$ & $52.6 \pm 3.0$ & $57.3 \pm 3.3$ & $62.8 \pm 2.0$ \\
\hline $\begin{array}{l}\text { 肥満度 } \\
\text { (カヴ指数) }\end{array}$ & $20.4 \pm 2.1$ & $20.3 \pm 0.8$ & $20.6 \pm 1.1$ & $22.4 \pm 0.9$ & $24.6 \pm 1.0$ \\
\hline
\end{tabular}


(3)心拍数測定（運動負荷実施時)

(4)二酸化炭素分圧測定 (呼吸法実施時)

\section{2. 運動負荷実施方法}

運動負荷実施方法は, 安静 2 分間を前後にとり, $4 \mathrm{METS}$ 設定で, 最高速度毎時 2 マイル, 角度 5 \%の運動負荷を10分間実施した。

全対象について運動負荷によるMETS 值の変 化をみると，図1のとおり平均して目標值の 4 METSの負荷が行われている。METS とは安静 時を基準にした運動，作業時のエネルギー消費を 定めたもので, 1METSは安静坐位で約 $3.5 \mathrm{ml} /$ $\mathrm{kg} / \mathrm{min}$ の酸素消費量であり, 4METSの運動量 は家事労働に相当する。

\section{3. 呼吸法実施方法}

膝の下に枕を入れ仰臥位にて実施した。呼吸法 実施方法は安静 3 分間を各呼吸法の間にとり, 腹 式深呼吸 1 分間, 胸式深呼吸 1 分間, 短促呼吸 10 秒実施 10 秒休みを 3 回反復, 努責の代わりに実施
した息止めは 30 秒実施 30 秒休みで行った。各呼吸 法による呼吸数は表 2 のとおり, 安静時平均毎分 15回, 腹式深呼吸時, 胸式深呼吸時毎分 6 - 7 回, 短促呼吸時毎分 40 ～50回である。

\section{4. 使用機器}

(1)呼気ガス指標至適運動負荷装置

a 、エアロビクス・プロセッサー391(日電三栄)

b. 電動トレッドミル（タテベ青州堂）

c . 電動トレッドミル プログラムコントロー ラー (タテべ青州堂)

d. 電動トレッドミル メタボリクコントロー ラー（タテべ青州堂）

e.テレメーター式ハートモニター(日電三栄)

f. 4ch ペンレコーダー (日電三栄 $8 \mathrm{~K}$ )

(2)経皮炭酸ガス測定装置 (オキシカプノモニター SMS365，へリゲ社)

(3)乾式オートスパイロメーター（チェスト マイ クロスパイロ 298)

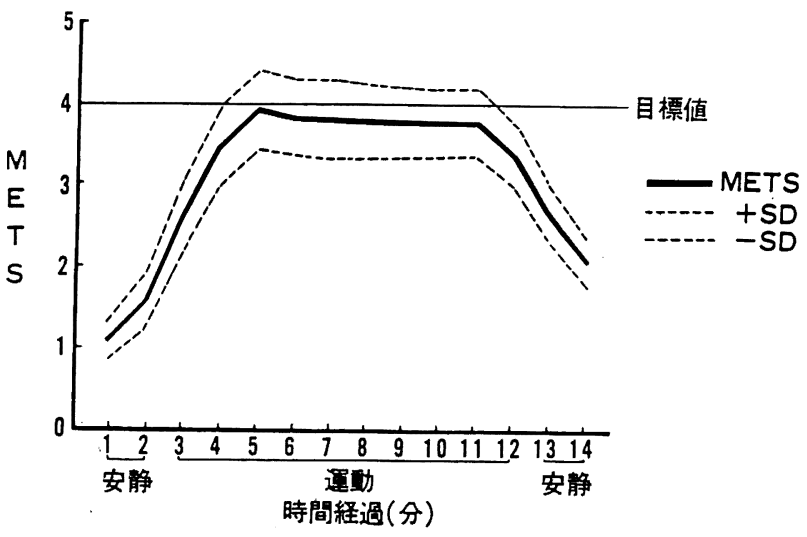

図 1 连動負荷によるME T S 值の変化

\section{IV 結 果}

\section{1. 肺機能測定}

肺機能測定の結果では表 3 のとお ク，努力性肺活量の平均は非妊婦では $3,173 \mathrm{ml}$ ，妊婦では初期 $3,147 \mathrm{ml}$ ，中期 $3,213 \mathrm{ml}$, 後期 $3,213 \mathrm{ml}$ である。妊婦で は妊娠の初期においては低值であり， \%肺活量， 1 秒量， 1 秒率においても 同様の結果が得られた。非妊婦および 奸婦間では，著しい差は認められなか つた。

2. 運功鱼荷による換気量と心拍数 運動負荷による換気量についてみる

表 2 呼吸法による呼吸数

\begin{tabular}{|c|c|c|c|c|c|}
\hline 対象 & 非妊婦 & \multicolumn{3}{|c|}{ 妊 婦 $(\mathrm{N}=8)$} & 平均値 \\
\hline 呼吸法 & $(\mathrm{N}=25)$ & 初 期 & 中 期 & 後 期 & $(\mathrm{N}=33)$ \\
\hline 安静時呼吸 & $14.2 \pm 2.6$ & $15.3 \pm 3.5$ & $15.9 \pm 2.5$ & $15.8 \pm 3.3$ & $15.0 \pm 3.0$ \\
\hline 腹式深呼吸 & $7.7 \pm 1.8$ & $7.1 \pm 2.4$ & 8. $0 \pm 1.3$ & $7.8 \pm 1.8$ & $7.7 \pm 1.9$ \\
\hline 胸式深呼吸 & $7.4 \pm 1.6$ & $7.9 \pm 1.4$ & $7.6 \pm 1.1$ & $8.0 \pm 1.2$ & $7.6 \pm 1.4$ \\
\hline 短促呼吸 & $45.7 \pm 8.5$ & $50.0 \pm 10.3$ & $53.1 \pm 8.6$ & $47.0 \pm 9.0$ & 47. $9 \pm 9.4$ \\
\hline
\end{tabular}


表 3 肺機能の変化

\begin{tabular}{l|c|c|c|c}
\hline \multirow{2}{*}{ 対象 } & \multirow{2}{*}{$\begin{array}{c}\text { 非妊婦 } \\
(\mathrm{N}=25)\end{array}$} & \multicolumn{3}{|c}{ 妊 婦 $(\mathrm{N}=8)$} \\
\cline { 3 - 5 } & & 初 期 & 中 期 & 後 期 \\
\hline 努力性肺活量 $(\mathrm{ml})$ & $3173.2 \pm 332.9$ & $3147.5 \pm 570.5$ & $3213.8 \pm 644.7$ & $3213.8 \pm 705.2$ \\
\hline \%肺活量 $(\%)$ & $102.6 \pm 10.0$ & $102.5 \pm 17.5$ & $104.5 \pm 19.6$ & $104.5 \pm 21.7$ \\
\hline 1 秒量 $(\mathrm{m} 1)$ & $2670.8 \pm 335.3$ & $2441.3 \pm 507.0$ & $2633.8 \pm 552.2$ & $2541.3 \pm 573.0$ \\
\hline 1 秒率 $(\%)$ & $84.2 \pm 6.9$ & $77.0 \pm 12.0$ & $81.8 \pm 4.4$ & $81.2 \pm 4.2$ \\
\hline
\end{tabular}

(Mean \pm S.D.)

と図 2 のおり，実線で示した非妊婦 の運動負荷時の平均 $20 \mathrm{l} / \mathrm{min}$ に比べ, 妊婦では平均 $27 \mathrm{l} / \mathrm{min}$ と有意に多く $(\mathrm{p}<0.01)$, また, 妊娠初期に比べ妊 娠中期, 妊娠後期では有意に増加して いる $(\mathrm{p}<0.01)$ 。

心拍数の变化においても図 3 のとお り, 非妊婦の運動負荷時の平均 100 105回/ $\mathrm{min}$ に比べ妊婦は平均 110 120回/ $\mathrm{min}$ と有意に多く $(\mathrm{p}<$ $0.01)$, 妊娠初期に比べ妊娠中期, 妊娠 後期では有意に多くなっている（ $\mathrm{p}<$ $0.01)$ 。

3. 呼吸法による呼気ガス分析と二酸 化宸素分圧

呼吸法による呼気ガス分析の結果で は図 4, 図 5 のとおり, 妊婦では酸素 捸取量の平均は, 安静時190 210ml/ $\mathrm{min}$, 腹式深呼吸時は220 230ml/ $\mathrm{min}$, 胸式深呼吸時は235 295ml/ $\mathrm{min}$, 短促呼吸時は $260 \sim 300 \mathrm{ml} / \mathrm{min}$ と なっている。二酸化炭素排出量の平均 は, 安静時 $170 \sim 190 \mathrm{ml} / \mathrm{min}$, 腹式深呼 吸時 $240 \sim 260 \mathrm{ml} / \mathrm{min}$, 胸式深呼吸時 $240 \sim 300 \mathrm{ml} / \mathrm{min}$, 短促呼吸時 $250 \sim 290$ $\mathrm{ml} / \mathrm{min}$ であり，各呼吸法による有意 な差はないが, 各期とも安静時に比べ 腹式深呼吸, 胸式深呼吸, 短促呼吸実 施により酸素搨取量, 二酸化炭素排出 量は増加している。

呼吸法によるMETS 值の変化については，図 6 に示すとおり安静時は平均 $0.8 \sim 0.9 \mathrm{METS}$ で あるのに対し，呼吸法実施により非妊婦では

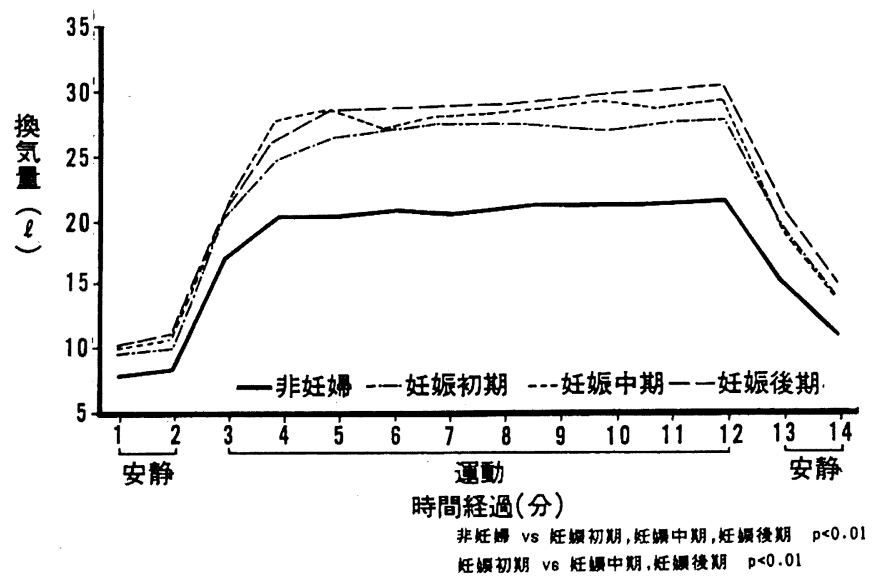

図 2 正枋負荷による換気贯の変化

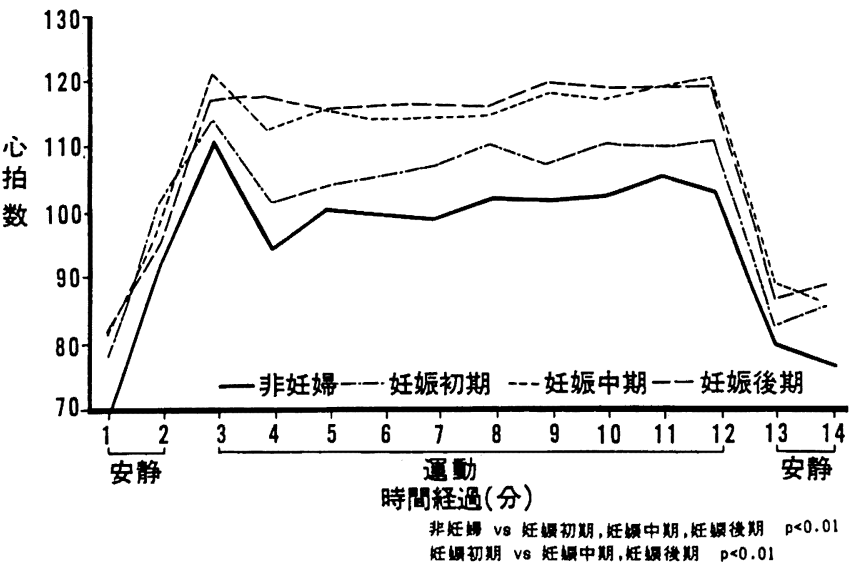

図 3 正劒負荷による心拍数の変化

1.2 1.8METS，妊婦では1.0〜1.4METS と安 静時に比べ高值を示し,特に短促呼吸においては, 安静時もしくは腹式深呼吸, 胸式深呼吸に比べ有 意に高值を示している（ $\mathrm{p}<0.01 ， \mathrm{p}<0.05) 。$ 


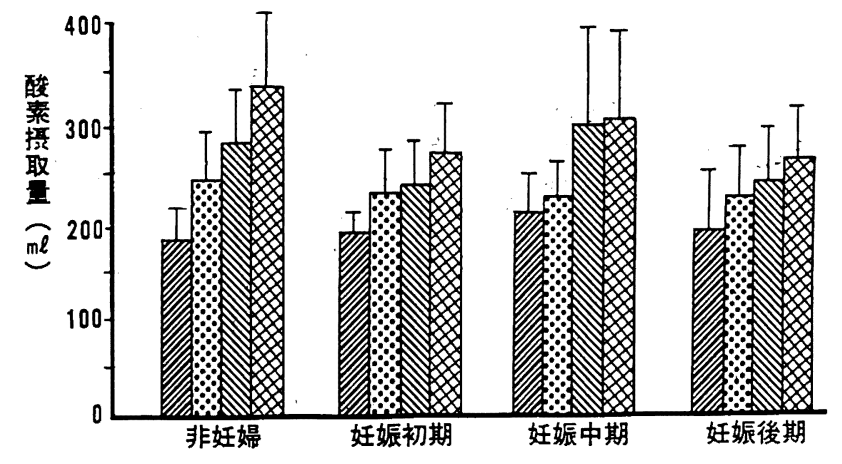

安安静時腹式深呼吸 $\mathbb{Q}$ 胸式深呼吸、短促呼吸

図4呼吸法による䣬素摄取田の変化

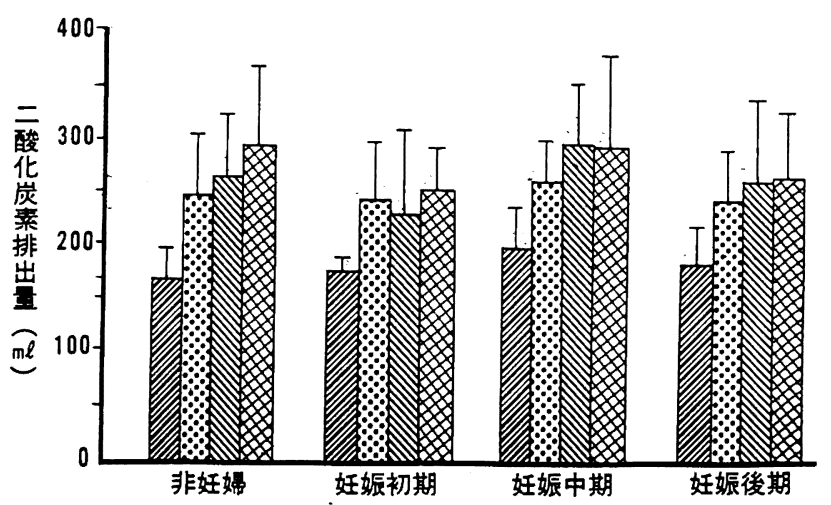

民安静時区腹式深呼吸 胸式深呼吸区短促呼吸

图 5 呼吸法による二酸化炭素排出田の変化

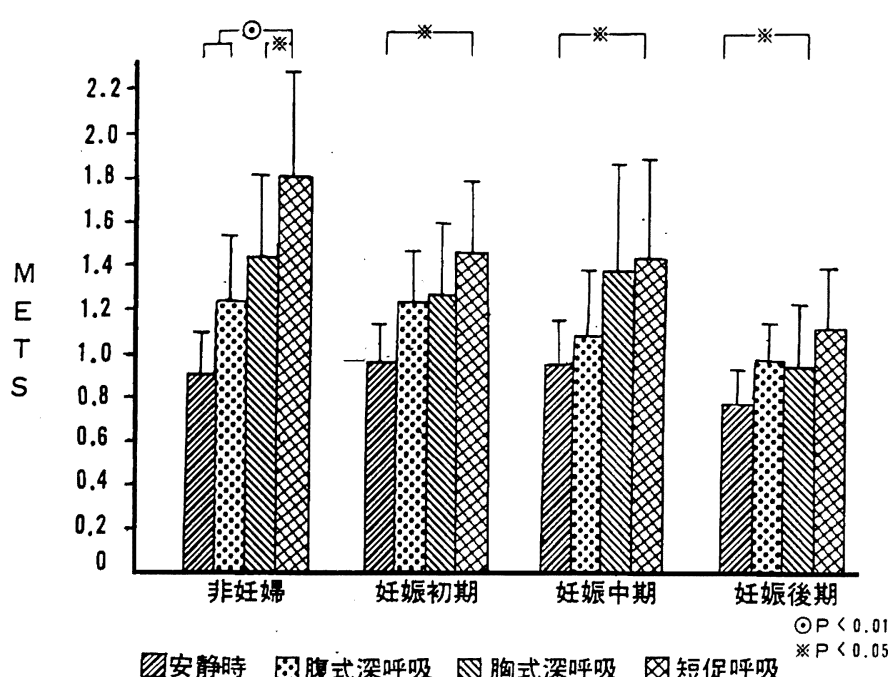

図6 呼吸法によるME T S 值の变化
呼吸法による換気量についてみると 図 7 のちり, 妊婦では腹式深呼吸時 の平均 $10 \sim 11 \mathrm{l} / \mathrm{min}$ と, 胸式深呼吸時 の平均 $10 \sim 13 \mathrm{l} / \mathrm{min}$ に比へ, 短促呼吸 時では平均 $15.5 \sim 17.5 \mathrm{l} / \mathrm{min}$ と有意に 増加しており, 非妊婦でも同じ傾向の 変加が認められる $(\mathrm{p}<0.01, \mathrm{p}<$ $0.05) 。$ 短促呼吸は呼吸 1 回当たりの換 気量は少ないが，1 分間の呼吸数が多 いためである。

呼吸法開始より二酸化炭素分圧の変 化をみると図8のとおりである。呼吸 法開始前の二酸化炭素分圧の值を 0 と して，低下したものには（一）の変化 率，上昇したものには $(+)$ の変化率 で表示した。腹式深呼吸, 胸式深呼吸, 短促呼吸により二酸化炭素分圧は低下 し，息止めでは上昇した。

二酸化炭素分圧の低下率は, 腹式深 呼吸, 胸式深呼吸実施時が $3 \sim 5 \%$ で あるのに対し，特に換気量の多い短促 呼吸実施時は 2 ～ $3 \%$ であり，妊娠各 期において有意に低值を示した（ $\mathrm{p}<$ $0.05, \mathrm{p}<0.01)$ 。

腹式深呼吸と胸式深呼吸を比較する と, 各期では有意な差はみられないが, 妊娠初期では腹式深呼吸実施により二 酸化炭素分圧の低下率が大きく，妊娠 中期, 妊娠後期では胸式深呼吸実施に より二酸化炭素分圧低下率の大きい傾 向がみられる。

息止めは，分婏時の努責にあたる反 応をみたものであるが，息止めによる 二酸化炭素分圧の上昇率は，妊娠初期 の約 $1 \%$ に比べ妊娠後期では約 $2 \%$ と 有意な差が認められ $(\mathrm{p}<0.05)$, 妊娠 経過とともに息止めによる二酸化炭素 の蓄積が増大する。

呼吸法終了から二酸化炭素分圧最大 変化までの時間は図9のとおり，腹式 深呼吸, 胸式深呼吸, 短促呼吸の場合 は平均40〜50秒であるのに対し，息止 めの場合は平均 80 秒であった。 


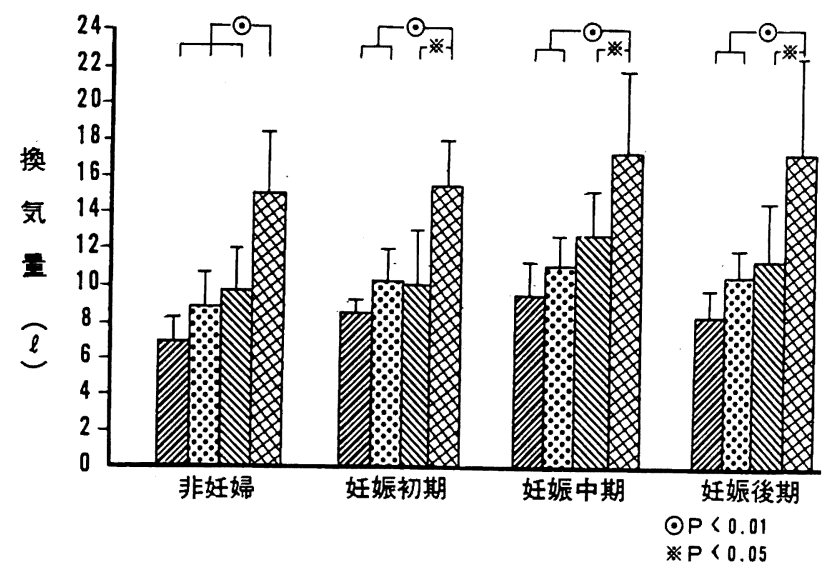

安静時䧗式深呼吸 胸式深呼吸短促呼吸

図 7 呼吸法による換気量の変化

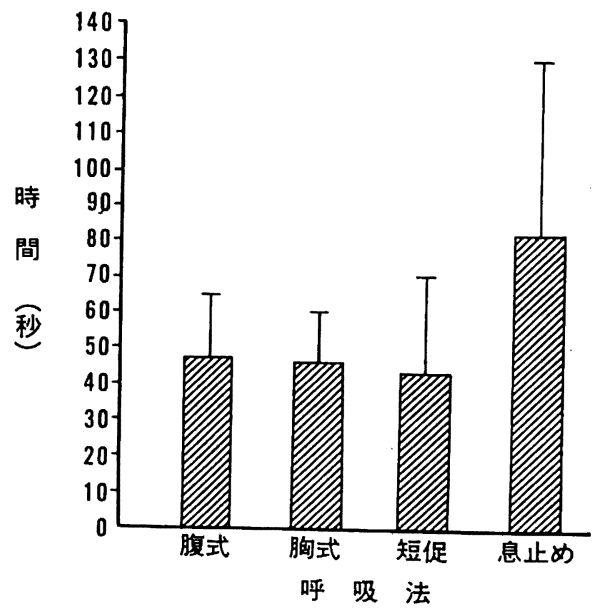

図 9 二酸化炭素分圧最大変化までの時間 (呼吸法終了から)

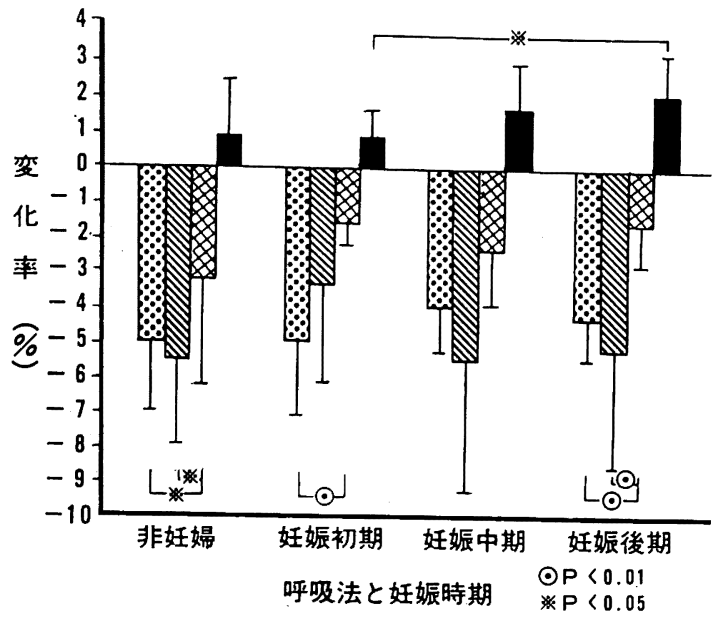

腹式深呼吸 $\mathbb{8}$ 胸式深呼吸 $\otimes$ 短促呼吸

息止め

図 8 呼吸法による二酸化炭素分圧の変化率

\section{$\mathrm{V}$ 考 察}

\section{1. 呼吸機能}

呼吸運動は, 肺胞内の空気を更新させるために, 胸郭の拡大と横隔膜の収縮によって他動的に行わ れる。

妊娠による胎児の成長は, 漸次子宮底を上昇さ せて肺への圧迫も增強すると考えられることか ら，経時的に呼吸機能の測定を実施した。

妊婦は, 肺活量, \%肺活量, 1 秒量, 1 秒率に ついて，非妊婦に比してやや低值を示すものの， 有意な差は認められず,いずれも正常範囲にある。
妊娠の時期による変化が認められないことから， 子宮増大に伴う横隔膜挙上は, 肺活量には大きな 影響はないといえる。

\section{2. 運動負荷による身体への影響}

運動時には, 筋活動の増大による酸素需要量を 満たすため, 酸素捸取の増加が要求されて分時換 気量は変動する。

運動開始して 2 分間ぐらいで定常状態に入り， 終了後速やかに回復している。今回は，定常負荷 として $4 \mathrm{METS}, 10$ 分間の運動であり，これは日 常動作に相当するが, 非好婦に比し妊婦の換気量 の増大, 心拍数の増加は著しい。また，妊娠の過 程に伴いその傾向は大きくなる。このような結果 より，妊娠により身体への負荷が増大し，特に妊 娠中期, 妊娠後期は日常生活動作, 家事労働にお いてもエネルギー消費の高いことがうかがえる。 しかしこれは, むやみに安静を強いる必要性を示 すものではない。近年, 妊婦体操, 妊婦水泳, 工 アロビクス等妊婦の運動療法が広く行われてい る。妊婦の運動療法実施により呼吸循環系の機能 に対する好影響についての勧めもあり，日常的に 身体的訓練を取り入れていくことは必要である。 そのため妊婦には不必要なエネルギーの消費を避 け，疲れを防ぎ，効率的に筋肉やエネルギーの使 用を考えさせることが必要である。

\section{3. 呼吸方法による検討}

自然分婏における呼吸法は，ゆっくりとした深 
い呼吸に始まり, やがて努責や短促呼吸が効果的 に実施されている。胸式呼吸は胸郭運動を中心と し, 腹式呼吸では横隔膜の収縮弛緩による。短促 呼吸では呼息による気管支運動が作用する。

腹式深呼吸, 胸式深呼吸はいずれも呼吸数を 1 分間 7 ～回で実施したが，妊娠中期，後期では 腹式深呼吸に比べ, 胸式深呼吸は換気量, 酸素摂 取量, 二酸化炭素排出量がやや多く, 二酸化炭素 wash out の効率も比較的良いことが認められた。 このことは, 妊娠子宮の增大が, 当然ながら腹式 深呼吸を困難にしていると考えられる。妊婦の呼 吸効率を向上させるためには妊娠初期から呼吸法 の訓練を行うことが大切であり，妊娠中期からは おもに胸式深呼吸の訓練を行い, 分婏時には酸素 供給を目的として, 胸式深呼吸または腹式深呼吸 を第一選択とし，過換気症候群にも注意しながら， ゆっくりとした呼吸を行うことが望ましいと考え られる。

肺胞内で酸素が血中に取り込まれ, 血液中の二 酸化炭素が肺胞内に排出される。ガス交換の効率 を二酸化炭素分圧の低下率または上昇率でみる と, 呼吸方法によって，また，妊娠の時期によっ てもその効率に違いがみられた。短促呼吸は酸素 搨取量, 二酸化炭素排出量, 換気量が多いにもか かわらず二酸化炭素分圧の低下率が低く, 二酸化 炭素 wash out の効率の悪いことが示される。こ の結果より短促呼吸は, 呼気と吸気の大部分が気 道内の dead space を往復しているのみで, 肺胞換 気にはつながっていないことを証明している。腹 式深呼吸, 胸式深呼吸は二酸化炭素分圧の低下率 が高く, 呼吸効率は良い。したがって分婏時の呼 吸法指導には, 酸素供給の目的としては腹式深呼 吸, 胸式深呼吸を第一選択として実施し, 短促呼 吸はリラクゼーションを目的としてのみ実施し， 短期間にとどめるべきであると考えられる。

息止めは分婏時の努責に相当する反応をみたも のである。二酸化炭素分圧の上昇率は妊娠後期ほ ど高くなること, 息止めを終了後 1 分以上経過し て二酸化炭素分圧が最高值になっているのは, 息 止めによって蓄積された二酸化炭素の排出に要す る時間が長いためと考えられる。したがって, 努 責後は二酸化炭素の wash out を速やかに, 効率 的に行うため, 十分な深呼吸を実施させる必要性
が考えられる。

\section{VI 結 語}

1. 肺活量については, 妊娠子宮増大による影響 は認められない。

2. 運動負荷により, 換気量や心拍数は妊娠の初 期に比べ，中期・後期には有意に増加し，エネ ルギー消費は高くなる。

3. 呼吸法によって酸素搨取量, 二酸化炭素排出 量は多くなる。

4. 胸式深呼吸, 腹式深呼吸では二酸化炭素分圧 の低下率が大きく，呼吸効率は良い。

5. 短促呼吸では換気量は多いが, 二酸化炭素 wash out の効率は悪い。

6.息止めによる二酸化炭素の蓄積は大きく，排 出に要する時間も長い。

上記の結果より，妊娠および分婏時には，目的 に応じた呼吸法を正しく選択し，呼吸数や呼吸効 率を考虑して，ゆっくりとした深呼吸の実施につ いて指導しなければならない。

\section{謝 辞}

本研究を実施するに当たり，ご指導ご協力をいただ いた信州大学医療技術短期大学部理学療法学科藤原 孝之助教授に深謝いたします。

\section{参考文献}

1）雨宮良彦，他：病院でのラマーズ法，その問題点と寒 際のあり方, ペリネイタルケア1(1)，22-28, メディカ 出版, 1982。

2) Catherine A. Collings, M. S., Luis B. Curet, M. D., John P. Mullin, Ph. D.: Maternal and fetal responses to a maternal aerobic exercise program, Am. J. Obstet. Gynecol., Vol. 145, 702-707, 1983.

3) H. Bartels., K. Riegel., J. Wenner., H. Wulf 著, 榎泰 義訳：周産期の呼吸生理一その基䃈と臨床的応用一, 真興交易医書出版部，第 1 刷，1975。

4）入内島明美：私の行う助産法一呼吸法を中心として, 母情生, 22(4)，28-35，1981。

5) Joseph Seitchik, M. D.: Body composition and energy expenditure during rest and work in preg. nancy, Am. J. Obstet. Gynecol., Vol. 97, 701-713, 1967.

6) Kent Ueland, M. D., Miles J. Novy, M. D., Edward N. Peterson, M.D., James metcalfe, M.D.: Maternal cardiovascular dynamics, Am. J.Obstet. Gynecol., Vol. 104, 856-864, 1969.

7）笠則義：メタルオキサイド $\mathrm{pH}$ 電極を用いた経皮的炭 
酸ガス分圧測定装置の検討, 周産期医学, 16(1)，139143，1986。

8）吉良枝郎：妊娠出産と母体の呼吸機能一妊婦の換気量 の增加を中心に一，助産婦，30(6)，18-23，1976。

9）岸英子，他：Read 法と Lamaze 法の呼吸法に関する 比較研究一フローホリリームリー夕゙使用による検討 一，母性衛生，24(1)，76-81，1983。

10）小林隆, 他：ラマーズ法の基礎と実際, 医学書院, 1981。

11) L. Dibblee, T.E. Graham. : A longitudinal study of changes in aerobic fitness, body composition, and energy intake in primigravid patients, Am. J. Obstet. Gynecol., Vol. 147, 908-914, 1983.

12）丸田和夫：エネルギー消費の計測，理学療法，4(1)，47 $-53,1987$ 。

13) Mark J. Morton, M.D., Marilyn S. Paul. B.A., Gerry R. Campos, M. D., Mark V. Hart, M. S., and James Metcalfe, M.D.: Exercise dynamics in late gestation: Effects of physical training, Am. J. Obstet. Gynecol., Vol. 152, 91-97, 1985.

14）目崎登，他：妊婦とスポーツ，基本的な考之方と原則 論, 周産期医学, 18(2)，187-190，1988。
15）宮本昭子，他：妊婦の呼吸管理に関する一考察，母性 衛生, 24(2), 31-33, 1983。

16）妊産婦体操編集委員会編：新版妊産婦体操の理論と実 際，47-84，全国母子健康センター連合会，1983。

17）尾島信夫：ラマーズ法の理念と術式の基準, ペリネイ タルケア，1(1)，9-21，メディカ出版，1981。

18) Pat J. Kulpa, M. D., Bridget M. White, M. A., and Robert Visscher, M. D.: Aerobic exercise in pregnancy, Am. J. Obstet. Gynecol., Vol. 156, 1395-1403, 1987.

19) Sachio Ogita, Shigeki Matsuo, Tomoko Oka, Ryoichi Kawabata, Masahiko Matsumoto, Yuji Fujino, Yuko Uramae, Koichi Iwanaga and Masanobu Fukuoka: Significance of Exercise and Bed Rest in Pregnancy-Pregnancy and walk(1)-, Ann. Physiol. Anthrop. 8(1), 13-19, 1983.

20）三野宮節子：分婏時の産痛楥和一ラマーズ法は分婏時 の産婦にどのような効果を与えるか一，母性衛生，24 (2), 65-67, 1983。 